\title{
Evaluation of Metal Pollution in Sediments and Water of Sao Marco Harbor (Maranhão, Brazil)
}

\author{
Delgado J de F, Lima L da S; Britto E B C C, Almeida M P, Vieira K S, Amorim R M, Baptista Neto J A and Fonseca \\ E M* \\ Graduation Program in Dynamics of Oceans and Earth, Fluminense Federal University, Brazil
}

Submission: July 28, 2020; Published: September 01, 2020

Corresponding author: Fonseca E M, Graduation Program in Dynamics of Oceans and Earth, Fluminense Federal University, 5 Niterói/RJ, Caixa Postal: 106051, CEP: 24230-971, Brazil Email: oceano25@hotmail.com

\begin{abstract}
The assessment of pollution in poor regions remains a challenge for developing countries. Difficult access to and low availability of logistical conditions result in a lack of information on environmental quality in these regions. To provide information on heavy metals concentrations in water and sediments, samples were collected in seven sampling stations in São Marco Bay's harbor area, seasonally, from August 2017 to September 2018. Water samples were evaluated for temperature, turbidity, salinity, Eh, oxygen content, pH, phosphorus, total organic carbons, and heavy metals. In sediment samples, heavy metals' potentially mobilizable fractions were evaluated. In parallel, grain size, organic matter and redox potential were also analyzed. The average values of water and its physicochemical parameters revealed an unstratified environment with a great influence of ocean waters. High concentrations of metals were recorded in the water of sediment contamination. The present study suggested the high hydrodynamics and resulting coarser grain size accumulation as the cause for the relatively balanced environment conditions.

Kewords: Contaminants; Physicochemical parameters; Seasonal variation
\end{abstract}

\section{Introduction}

Anthropogenic contaminants discharged into aquatic environments can cause negative impacts to marine biota, especially in urbanized, industrialized or harbor sites [1]. As a result of the low hydrodynamics and inherent protection against waves and strong currents, estuarine areas tend to concentrate contaminants. This is the same reason why pollutant levels are generally higher in estuaries than in the open sea. Many harmful pollutants found in trace levels in water may accumulate to elevated concentrations in sediments. Thus, sediments act both as reservoirs and sources of contaminants to the water column and tend to integrate contaminant concentrations over time [2]. Regardless of the source, contaminants such as heavy metals are potentially adsorbed to fine-grained and organic rich sediments $[3,4]$. These contaminants tend to deposit in hydrodynamically quiet areas like estuaries and bays [5], where the low circulation allows stabilization of finer particle fractions and maintenance of subtoxic patterns, which in turn allows the retention of organic matter.
Potentially toxic metals may occur mainly due to industrial and agricultural wastes [6-8]. Some metals are essential for living organisms, such as $\mathrm{Cu}$ and $\mathrm{Zn}$ [9]. However, some are toxic to living organisms [10]. Lead, Arsenic, Mercury, and Cadmium, for example, are considered some highly toxic metals whose widespread use has caused extensive environmental contamination and health problems in many parts of the world [11]. Heavy metals are regarded as especially dangerous contaminants because of their environmental persistence, toxicity, and ability to be incorporated into food chains [12]. The strongest toxic properties are characteristic of inorganic metals compounds, which are easily soluble [13]. Some heavy metals dissolve immediately and tend to accumulate in aquatic organisms [14].

After entering the aquatic environment, heavy metals tend to be sequestered at the bottom [15]. They tend to be adsorbed into inorganic and organic particulates and finally incorporated into sediment compartments, generating elevated levels of heavy metals in bottom sediments [16]. On the other hand, heavy metals 
are not necessarily stored in sediments permanently. Some of the sediment-bound metals may remobilize and be released back into the water through a variation of environmental conditions [17]. The distribution processes of the metals entering natural waters are controlled by a dynamic set of physicochemical interactions, and their solubility is controlled mainly by hydrogen ionic potential $(\mathrm{pH})$, type of metal species, organic matter content, the oxidation state of mineral components and the redox environment of the aquatic system $[18,19]$.

The Brazilian coastline presents a great diversity of geomorphological features [20], with many bays and estuaries, where different economic activities with great polluting potential exist. Port terminals and harbor areas have great importance in the economy around the globe. However, their operation has been very impactful on marine and coastal ecosystems [21]. Despite being a consequence of port operation, aquatic pollution represents a problem in port management, especially about potentially toxic metals. The aim of this study is to evaluate the metal concentrations in water and sediment samples collected in São Marco Bay harbor area.

\section{Study Site}

The northern coast of Brazil is characterized as an extremely irregular shoreline [22], formed by many estuaries extending from São Marcos Bay, in Maranhão State, up to the extreme north of Amapá State [23]. São Marcos bay is an active estuary, spread approximately $100 \mathrm{~km}$ in length, with the hydrographic basin composed of Grajaú, Mearim, and Pindaré rivers (Figure 1). The climate is formed by two main seasons: a rainy and a dry season [24] (Figure 2). The hydrodynamic regime is characterized by a semidiurnal macrotide with current velocities higher than $1.1 \mathrm{~ms}^{-1}$ (maximum tidal currents of $2.42 \mathrm{~ms}^{-1}$ ) [25]. The bay is surrounded by a wide mangrove environment [26]. The entrance of the bay presents a width of $\sim 55 \mathrm{~km}$, which narrows to $1.5 \mathrm{~km}$ at the intersection of Pindaré and Mearim rivers.

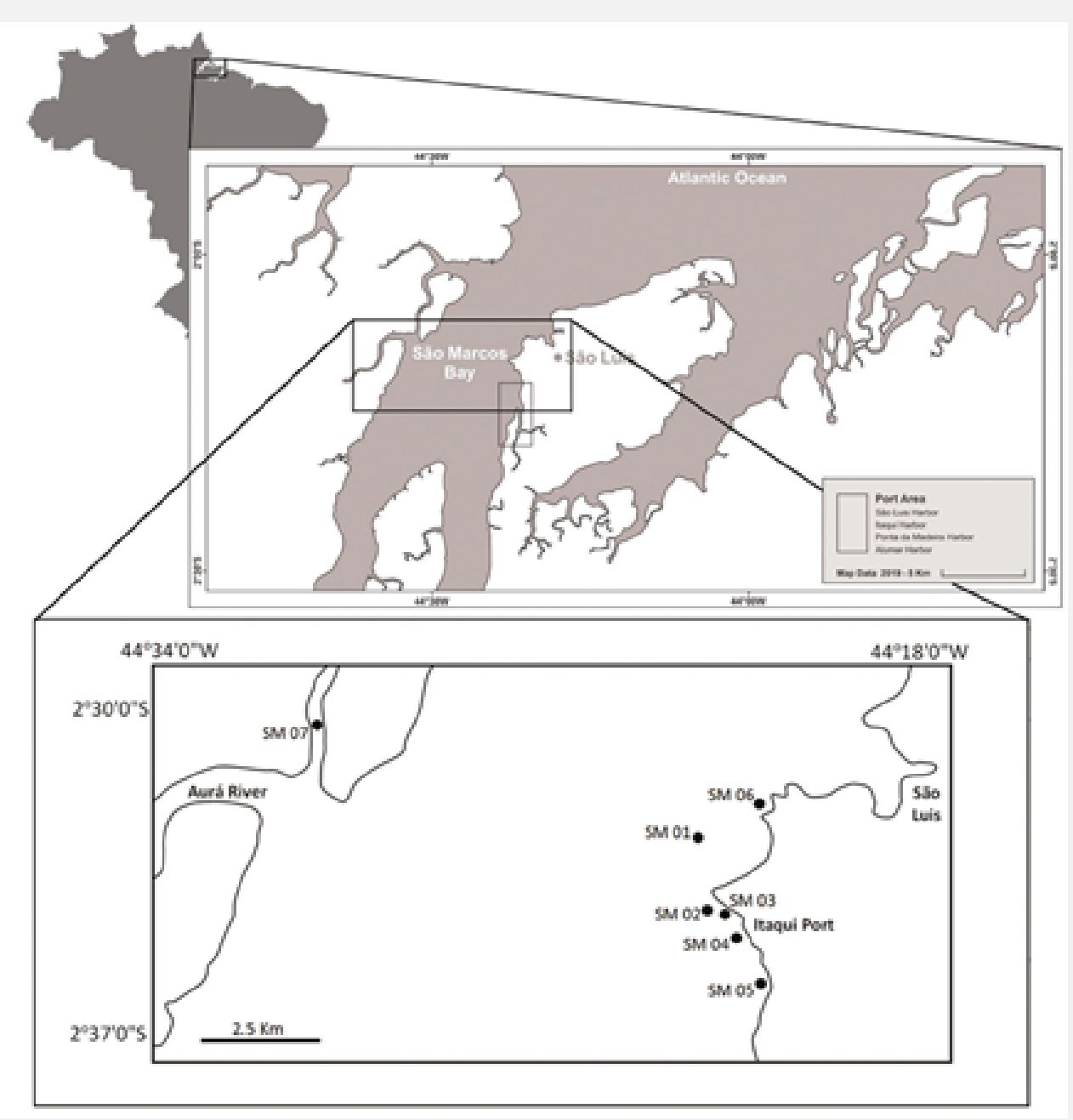

Figure 1: Study Site. 


\section{Oceanography \& Fisheries Open access Journal}

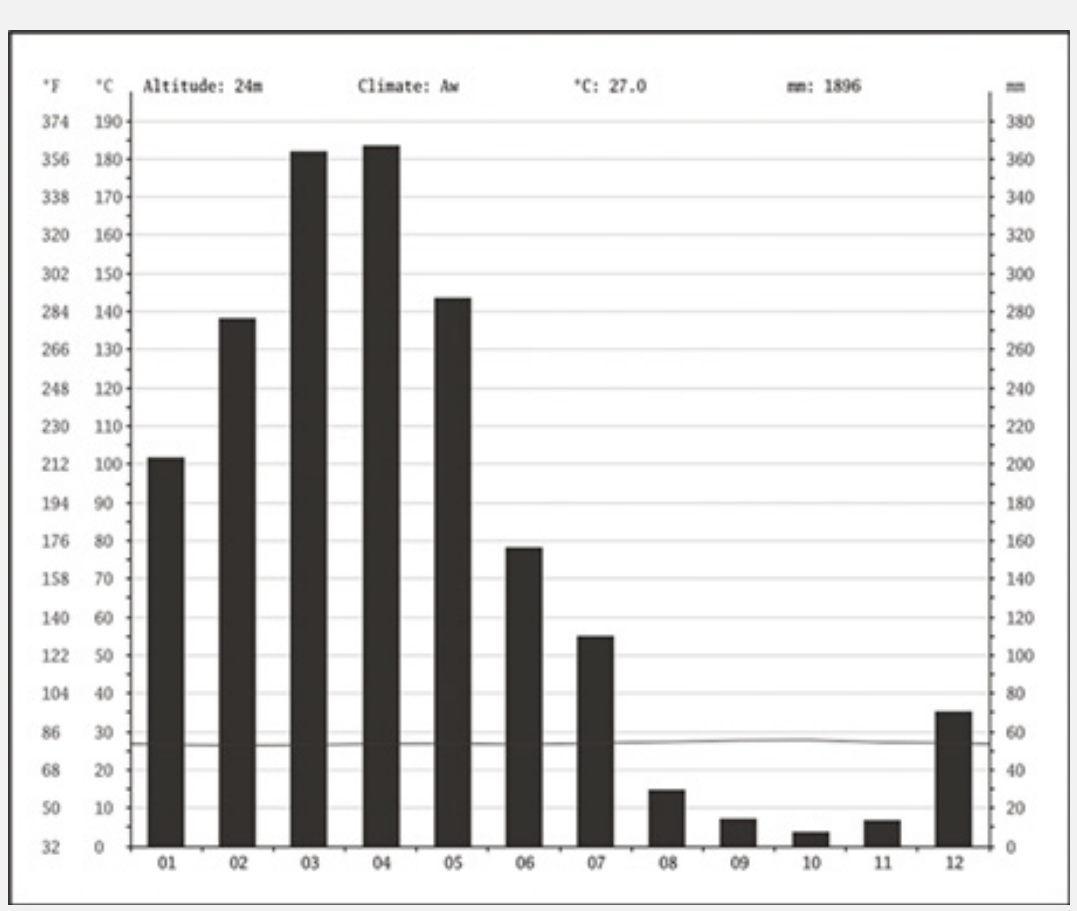

Figure 2: Typical pluviogram of the city of Sao Luiz (Source: Climate-data.org).

The bay contains a central channel with depth measuring up to $90 \mathrm{~m}$, which works as a waterway for the second-most important port complex of Latin America, which includes São Luís harbor, Itaqui harbor, Ponta da Madeira port terminal and Alumar port terminal [27]. Ponta da Madeira terminal passed through an expansion to increase its export capacity to 235 million tons per year of iron mineral, becoming the port with the largest volume of cargo in Brazil. In addition to ore export, the region has steel and aluminum mills, such facilities representing the major economic activity of the region [25]. Finally, São Marcos Bay represents an important fishing spot. In the last few decades, chemical pollution of that environment due to sewage discharge, the nutrient runoff from pesticides, and industrial waste have impacted the region. Combined with the unsustainable use of resources, this has had an increasing threat to the health of aquatic organisms [28].

\section{Materials and Methods}

Four seasonal field campaigns were carried out, during ebb tide, from August/2017 to September/2018, when seven sampling stations were established and marked using global positioning system coordinates.

Physicochemical parameters (temperature, $\mathrm{pH}$, dissolved oxygen levels (DO), salinity and redox potential) were analyzed in situ, using a multi parameter probe (Horiba U-51). Surface water samples were obtained with a 5L Van Dorn bottle. Water was analyzed for Total Organic Carbon (TOC), Phosphate, and Metals ( $\mathrm{Pb}, \mathrm{Cu}, \mathrm{Cr}, \mathrm{Cd}, \mathrm{Ni}, \mathrm{Zn}$, and $\mathrm{Hg}$ ) and As. Water samples were filtered through $0.45 \mu \mathrm{m}$ cellulose acetate membrane filters using a vacuum filtration, preserved in plastic bottles (Polypropylene bottles) and maintained in cooler boxes until laboratory analysis.

For heavy metals analysis, the sampling bottles were preconditioned with 5\% nitric acid and later rinsed thoroughly with distilled de-ionized water. At each sampling site, the polyethylene sampling bottles were rinsed at least three times before sampling was done. About $0.5 \mathrm{~L}$ of the water samples were taken at each sampling site. Samples were acidified with $10 \% \mathrm{HNO}_{3}$, placed in an ice bath and brought to the laboratory. Sediment samples were collected at each site using a Van Veen grab to determine the sediment grain size, TOC, Phosphate and Metals $(\mathrm{Pb}, \mathrm{Cu}, \mathrm{Cr}, \mathrm{Cd}$, $\mathrm{Ni}, \mathrm{Zn}$, and $\mathrm{Hg}$ ) and As. After sampling, sediment samples were properly stored in a cooler box.

\section{Water Analysis}

Total Organic Carbon was determined using a dry combustion method with a Perkin Elmer 2400 CHN (carbon, hydrogen, and nitrogen) analyzer (series II). The instrument was calibrated using standard solutions of potassium hydrogen phthalate, diluted to different concentrations according to the estimated TOC content of the samples. The value obtained for each sample was the average of at least three satisfactory injections in terms of the coefficient of variation $(\leq 2 \%)$. Total phosphorus concentrations were obtained by persulfate oxidation [29]. The concentrations of heavy metals $(\mathrm{Pb}, \mathrm{Cu}, \mathrm{Cr}, \mathrm{Zn}$, and $\mathrm{Ni}$ ) and as were measured by Inductively Coupled Plasma-Mass Spectrometry (ICP-MS, Thermo Fisher scientific X series 2). Cd and Hg were measured by Inductively Coupled Plasma-Mass Spectrometry (ICP-MS, Thermo Fisher scientific X series 2). 


\section{Sediment Analysis}

The sediment grain size was measured by wet sieving and pipette analysis as described by Hsieh (1995). The samples were transferred to the laboratory and frozen $\left(\sim-20^{\circ} \mathrm{C}\right)$ until analysis. Freeze-dried sediment samples were first heated at a relatively low temperature $\left(60^{\circ} \mathrm{C}\right)$, after $2-3$ treatments with $2 \mathrm{~N} \mathrm{HCl}$ to remove inorganic carbon. TOC concentrations were determined using a PerkinElmer Series II CHNS/O analyzer, Model 2400. Total Phosphate was obtained after the sample ignition at $550^{\circ} \mathrm{C}$ for 12 hours. Ashes were digested by $\mathrm{HCl} 1.0 \mathrm{M}$ under stirring.

Heavy metal samples were placed into acid-washed plastic bags and transported to the laboratory where they were wetsieved, and fractions $<0.063 \mathrm{~mm}$ analyzed for geochemical parameters. The digestion method to extract heavy metals was based on the USEPA Method 3051A [30,31]. 0.5-g dry weight (dw) were digested with $10 \mathrm{~mL}$ of $\mathrm{HNO}_{3}$ in a Microwave Sample Preparation System (Model 1000, CEM Corp, Matthews, NC). Acidified sediment extracts were filtered through a Whatman 41 filter paper, diluted to $50 \mathrm{~mL}$ with distilled deionized water (ddw), and stored in $60 \mathrm{~mL}$ polypropylene Nalgene bottles. Digestion for Hg determination was based on the USEPA Method $7471 \mathrm{~A}$ [30].

Briefly, about $1 \mathrm{~g}$ dw equivalent of each sample was digested with $5 \mathrm{~mL} \mathrm{H} 2 \mathrm{SO} 4$ and $2.5 \mathrm{~mL} \mathrm{HNO3.} \mathrm{Samples} \mathrm{were} \mathrm{placed} \mathrm{in} \mathrm{a}$ water bath at a temperature of $95{ }^{\circ} \mathrm{C}$ for two minutes. When samples achieved room temperature, $25 \mathrm{~mL}$ of ddw and $40 \mathrm{~mL}$ of $5 \% \mathrm{w} / \mathrm{v} \mathrm{KMnO}_{4}$ were added. Samples were placed back in the water bath for one hour. Digested samples were diluted to 100 $\mathrm{mL}$ with $\mathrm{ddw}$ and discolored with $10 \mathrm{~mL}$ of a sodium chloridehydroxylamine sulfate solution. The heavy metals $\mathrm{Pb}, \mathrm{Cu}, \mathrm{As}, \mathrm{Cr}$, $\mathrm{Ni}, \mathrm{Zn}$ and $\mathrm{Ni}$ ) concentrations of the solutions were measured by Inductively Coupled Plasma-Atomic Emission Spectrometry (ICP-AES, Perkin Elmer Optima, 2000DV), and Cd and Hg were measured by Inductively Coupled Plasma-Mass Spectrometry (ICP-MS, Thermo Fisher Scientific X series 2)

For quality control, reagent blanks, standard reference materials (GBW07333), and sample replicates were inserted in the analysis. All reagents were ultrapure and glassware/ plastic ware/filters cleaned according to the method of Harrison and Laxen (1980). The result showed that there was no sign of contamination in the analysis and all the relative standard deviations of the replicate samples were $<10 \%$. The recovery rates for the heavy metals in the GBW07333 standard were higher than $82 \%$. Mean recoveries were as follows: $\mathrm{Pb}, 92.0 \%$; $\mathrm{Cu}, 95 \%$; Cd, 82 \%, As, 78 \%, Cr, 89.0 \%; Ni, 85 \%; Zn, $84 \%$ and $\mathrm{Hg}, 92 \%$. The detection limits of the method are respectively: As, $1 \mathrm{mg} \mathrm{Kg}^{-1}$; $\mathrm{Cd}, 0.1 \mathrm{mg} \mathrm{Kg}^{-1} ; \mathrm{Pb}, 0.4 \mathrm{mg} \mathrm{Kg}^{-1} ; \mathrm{Cu}, 0.1 \mathrm{mg} \mathrm{Kg}^{-1} ; \mathrm{Cr}, 0.1 \mathrm{mg} \mathrm{Kg}^{-1} ; \mathrm{Hg}$, $0.02 \mathrm{mg} \mathrm{Kg}^{-1}$; $\mathrm{Ni}, 0.4 \mathrm{mg} \mathrm{Kg}^{-1}$ and $\mathrm{Zn}, 0.4 \mathrm{mg} \mathrm{Kg}^{-1}$.

The sediment properties and total metal concentrations from different sampling stations were compared using multivariate analysis of variance (ANOVA) and Tukey test followed by a Pearson significant correlation test. Normality of the data was tested with the Shapiro-Wilk test prior to analysis. Finally, the assessment of sediment elements enrichment was carried out through the calculation of the geo accumulation index (Igeo). Igeo was originally used in bottom sediments by Muller [32] enabling the contamination assessment by comparing the current levels of metal concentrations and the original preindustrial concentrations in the soils. This index is computed by the following equation:

where:

$$
\text { Igeo }=\log 2\left[\frac{C n}{1.5 B n}\right]
$$

$\mathrm{Cn}=$ Measured concentration of the element in the tested sediment

$\mathrm{Bn}=$ Geochemical background value of the element in fossil argillaceous sediment.

The present work considered the values reached by Rudnick \& Gao [33]. The constant 1.5 is introduced to minimize the effect of possible variations in the background values that may be attributed to lithologic variations in the sediments. The following interpretation for the Igeo is given [32,34]: Igeo $<0=$ practically unpolluted; $0<$ Igeo $<1=$ unpolluted to moderated polluted; 1 $<$ Igeo $<2=$ moderately polluted, $2<$ Igeo $<3=$ moderately to strongly polluted; $3<$ Igeo $<4=$ strongly polluted; $4<$ Igeo $<5=$ strongly to extremely polluted; and Igeo $>5=$ extremely polluted. In this study, we used the Igeo index using grain fraction $<0.063 \mathrm{~mm}$ according to González-Macías et al [25].

\section{Results and Discussion}

\section{Water}

The physicochemical conditions of surface and bottom water in the São Marco Bay were recorded from August/2017 to September/2018, showing temperature variation ranging from 24.9 to $29.6^{\circ} \mathrm{C}$ and the highest and the lowest values were recorded in February (rainy season). In general, in the present study, temperatures at the bottom and surface appeared to be similar, suggesting a negligible thermal stratification in the water column (Figure 3). The ANOVA test did not confirm the water column thermal stratification to be significant ( $p>0.05)$.

On the other hand, temperature can promote direct impacts on fauna and flora physiological processes involving oxygen consumption/production balance. Also, temperature can stimulate planktonic and benthic respiration rates [35]. It is assumed that primary production is also enhanced in the summer in many temperate estuarine zones [36], while an accumulation of phytoplankton biomass can result in bottom-water oxygen depletion [37]. Temperatures recorded in the August campaign were significantly lower than in the other campaigns (ANOVA: $p$ $<0.05$ ). Rodrigues et al. [38] recorded similar thermal patterns during two years of monitoring in areas adjacent to the present study site. 


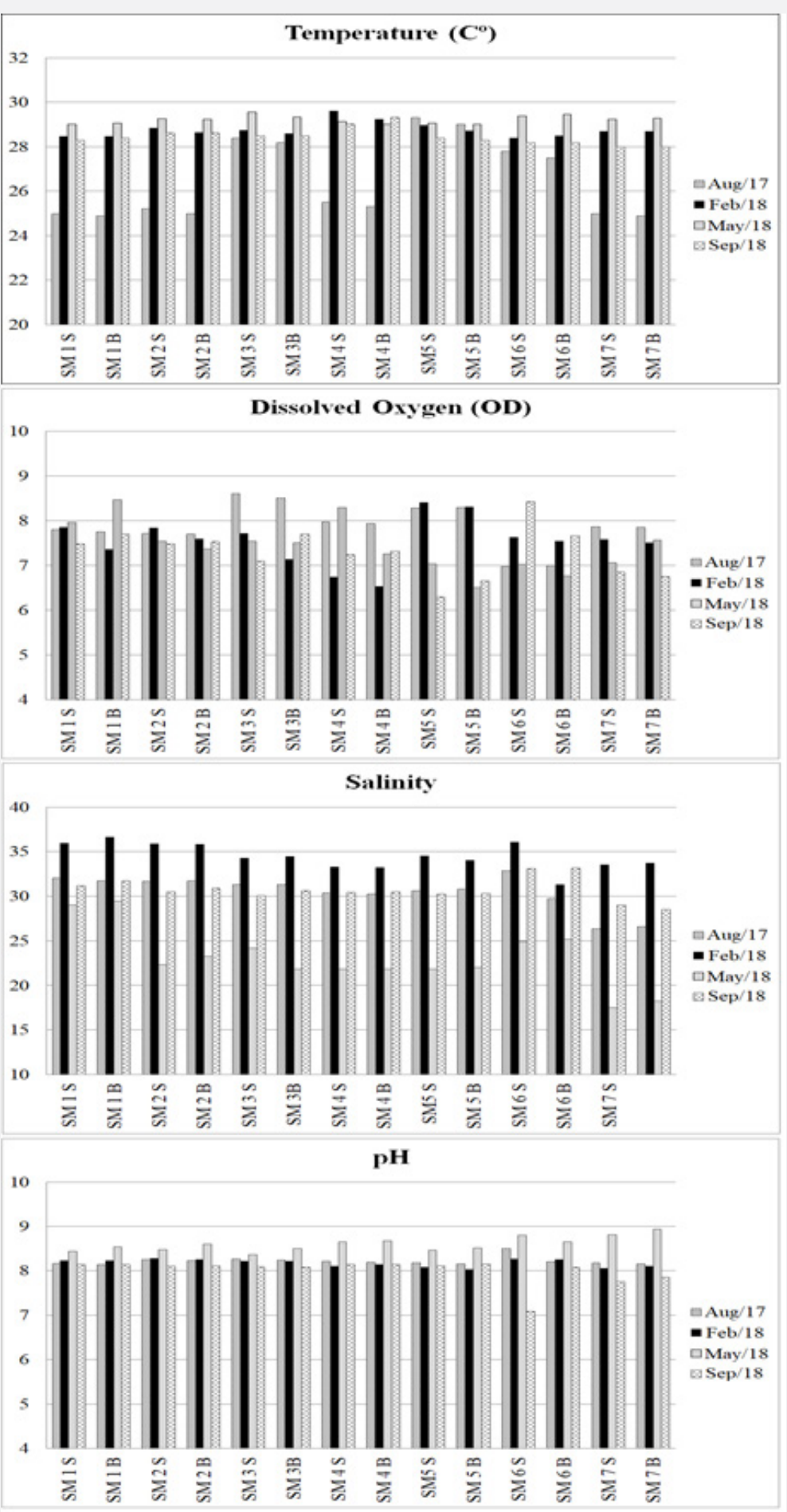

Figure 3: Water column physicochemical results.

The anthropogenic acidification of estuarine water can cause several negative impacts on primary and secondary producers. Additionally, because of the high levels of some ions, like bicarbonate and calcium, seawater presents significant buffering capacity against $\mathrm{pH}$ changes [31]. In the open ocean, seawater typically varies between 7.8 to 8.4. In coastal areas such estuaries, on the other hand, $\mathrm{pHs}$ can reach considerably lower values (7 into strongly acidic conditions). In the present study, the recorded 
$\mathrm{pH}$ values showed to be predominantly basic, suggesting the influence of the open sea carbonate system [39], varying between 7.09 in September to 8.94 in May (Figure 3).

According to the ANOVA test, no significant statistical variation was found between sampling depths ( $p>0.05)$, suggesting the predominance of seawater influence. GonzálezGorbeña et al. [25] confirmed the significant power of tidal currents in the study site, suggesting tides as the most important local energy component. This feature may interfere considerably with the quality of the water, promoting turbulent mixing and not allowing the stratification of the water column. Estuaries tends to exhibit significant spatial and temporal variation in dissolved oxygen levels across the ecosystem [37]. Within this context, high oxygen consumption rates can be due to direct organic discharges from the watershed or can be caused by phytoplankton blooms (autochthonous organic matter production) fed by inorganic nutrient loadings [40].

Additionally, it is now discussed that global warming may also result in changes in the dissolved oxygen content of coastal and estuarine waters [41]. The present study recorded levels of dissolved oxygen varying between 6.3 to $8.6 \mathrm{mg} \mathrm{L}^{-1}$, suggesting a relative intense oxygenation of the environment, because of the influence of the oceanic water into the system (Figure 3). Rodrigues et al. [38] reported mean levels of oxygen in the two mangroves in the vicinity of the study area, varying around $4 \mathrm{mg} \mathrm{L}^{-1}$, confirming the good oxygenation of the area, even in the mangrove areas. Cavalcanti et al. [42], on the other hand, recorded dissolved oxygen varying between $3.08 \mathrm{mg} \mathrm{L}^{-1}$ to $6.5 \mathrm{mg} \mathrm{L}^{-1}$, highlighting a seasonal pattern with significant differences between the rainy and the dry seasons, with higher values observed in the dry season and ebb tide.

The relatively high levels of oxygen can be attributed to the peculiar characteristics of São Marco Bay, since this bay is dominated by a macro tide regime where wind force also develops continuous vertical mixing of the water column, allowing the translocation of oxygen- saturated water and preventing proximate coastal water bodies from eutrophication since macrotidal currents decrease the response of primary production to enhanced nutrient inputs [43]. Salinity plays a crucial role and defines structural and functional dynamics of aquatic biota in estuarine environment [44]. As a result of the mixing of oceanic and continental waters, estuaries tend to have large salinity variations, both vertically and spatially [44].

Mainly, because of the estuarine mixture, heavy metals in different forms are influenced by various processes whose flocculation is one of these reactions [45], transferring heavy metals from soluble forms to particulate fraction. Our results varied between 17.5 in May and 36.6 in February, suggesting the alternation between continental and oceanic water presence (Figure 3). Salinity may vary daily with tidal cycles, or episodically due to rain events. ANOVA statistical analysis, on the other hand, did not show any significant variation between sampling stations or depths ( $p>0.05)$. Seasonal evaluation, on the other hand, showed significant differences for all the physical chemical parameters among different campaigns, suggesting an important climatological influence in the estuarine water dynamics $(\mathrm{p}<0.05)$.

According to Middelburg and Soetaert [46], in the watersediment interface, the stratification of biogeochemical processes corresponds to a vertical distribution of the electron-acceptor. The same authors argue that the processes that govern the fate of these substances in the sediment result from the complex interactions with the biogeochemical cycles of major redox and biogenic elements such as $\mathrm{C}, \mathrm{N}, \mathrm{O}, \mathrm{P}$ and $\mathrm{Si}$. So, in the present study, water oxidation-reduction potential varied between 124.8 and 239.2 (Figure 4), confirming an oxidant environment. In the sediment, on the other hand, results presented only negative values (between -90 and -155) suggesting a hypoxic environment. The sediment data can be explained because of the limited oxygen percolation horizon in sediments, varying between $1 \mathrm{~mm}$ (in fine muddy grain size) to a few $\mathrm{cm}$ (in coarser sandy sediments) [47]. Additionally, the organic matter is degraded by heterotrophic bacteria or respired and mineralized [48] stimulating the oxygen depletion rates [49], resulting in hypoxic or anoxic conditions and negative redox patterns.

The total phosphorus concentrations, varied between 0.07 and $26.40 \mathrm{mg} \mathrm{L}^{-1}$, presenting values higher than environments such as Guanabara Bay [50]. The concentrations of heavy metals in the water samples are shown in Figure $5 . \mathrm{Hg}, \mathrm{Ni}, \mathrm{As}, \mathrm{Pb}$, and $\mathrm{Cd}$ were below the detection limits, suggesting no anthropogenic source for these metals in the studied area. Concentration of $\mathrm{Cu}$ and $\mathrm{Cr}$ ranged between n.d. (not detected) - $3.95 \mathrm{mg} \mathrm{L}-1$ and

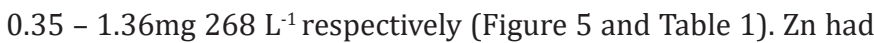
its highest concentration of $3.36 \mathrm{mg} \mathrm{L}^{-1}$ in August and its lowest concentration of $0.03 \mathrm{mg} \mathrm{L}^{-1}$ in February. Such results showed a significant difference among seasons, suggesting the solubilization of water heavy metals during rainy season and highlighting the local climatology as an important variable in the geochemical dynamics of the estuarine water. Carvalho et al. [51] determined the concentrations of $\mathrm{Cu}, \mathrm{Zn}, \mathrm{Pb}$, and $\mathrm{Cd}$ in the mussel Mytella falcata from the Bacanga River estuary, located in the same bay. These authors suggested that Zn presented slightly higher values than the maximum ones established by the Brazilian government, reinforcing the idea of the bioavailability of this metal.

\section{Sediment}

In the present study, the total organic carbon levels in the sediment varied between 0.54 and $0.91 \%$ (Table 2). Other studies developed in the Brazilian coast showed very similar levels $[52,53]$. The highest polluted areas in Brazil such as Guanabara Bay and Sepetiba Bay, on the other hand, present higher values (Table 2). Previous studies on sediment and water contamination in the studied area showed significantly higher levels of mercury and chrome, which confirms that São Marcos Bay is a site with 
high exposure risks for some contaminants [28]. The present because the samples were not collected in the same place, where study did not show the same pattern, where the concentration sedimentological characteristics may differ.

of $\mathrm{Hg}$ was below the detection limits of the method, probably

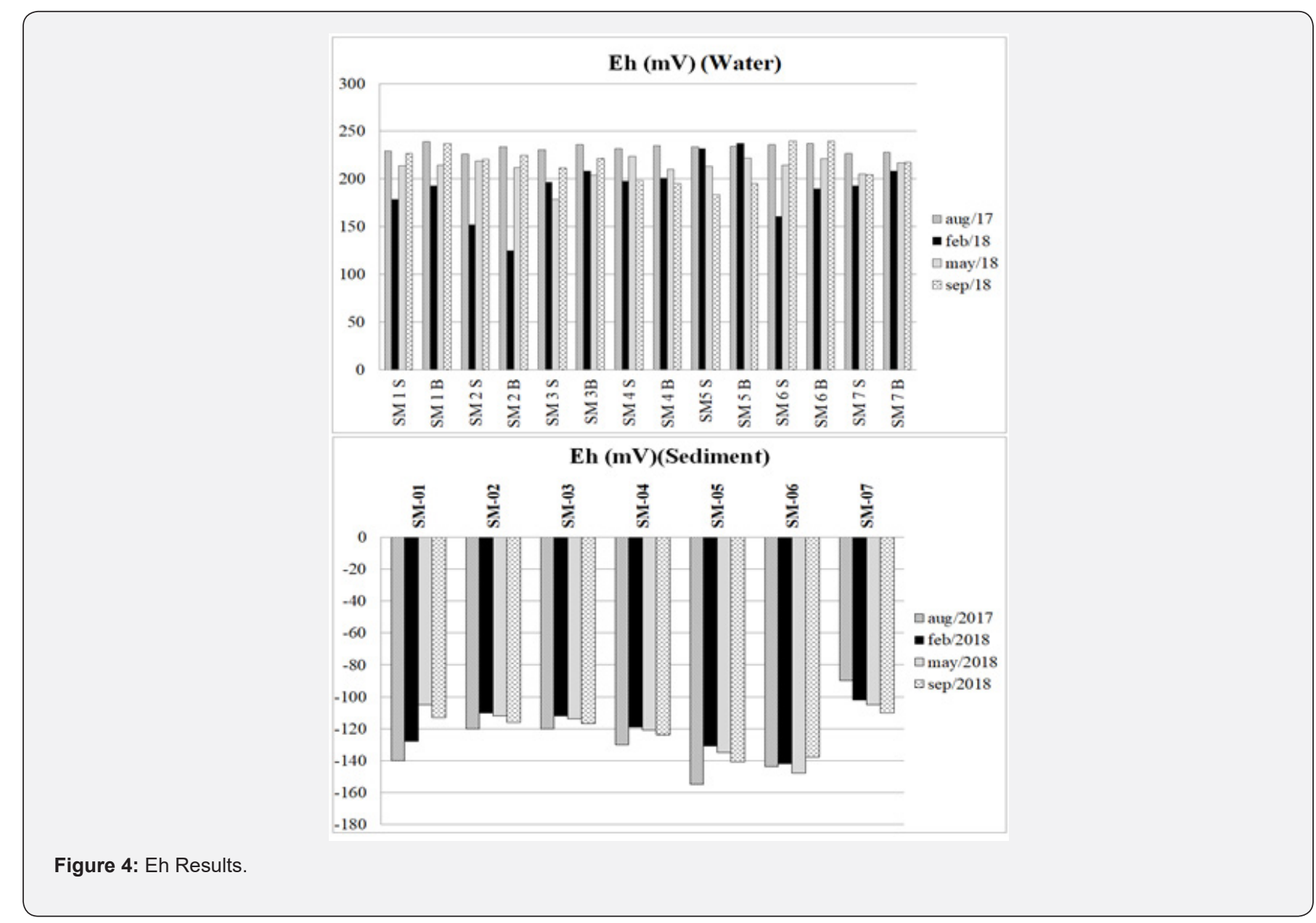

Table 1. Water analysis results.

\begin{tabular}{|c|c|c|c|c|c|c|c|c|c|c|c|c|c|c|c|c|c|}
\hline & & \multicolumn{4}{|c|}{ Total Phosphorus (mg L ${ }^{-1}$ ) } & \multicolumn{4}{|c|}{ Copper $\left(\mathrm{mg} \mathrm{L}^{-1}\right)$} & \multicolumn{4}{|c|}{ Chrome $\left(\mathrm{mg} \mathrm{L}^{-1}\right)$} & \multicolumn{4}{|c|}{$\operatorname{Zinc}\left(\mathrm{mg} \mathrm{L}^{-1}\right)$} \\
\hline & Date & $\begin{array}{l}\text { Aug- } \\
2017\end{array}$ & $\begin{array}{l}\text { Feb- } \\
2018\end{array}$ & $\begin{array}{l}\text { May- } \\
2018\end{array}$ & $\begin{array}{l}\text { Sep- } \\
2018\end{array}$ & $\begin{array}{l}\text { Aug- } \\
2017\end{array}$ & $\begin{array}{l}\text { Feb- } \\
2018\end{array}$ & $\begin{array}{l}\text { May- } \\
2018\end{array}$ & $\begin{array}{l}\text { Sep- } \\
2018\end{array}$ & $\begin{array}{l}\text { Aug- } \\
2017\end{array}$ & $\begin{array}{l}\text { Feb- } \\
2018\end{array}$ & $\begin{array}{l}\text { May- } \\
2018\end{array}$ & $\begin{array}{l}\text { Sep- } \\
2018\end{array}$ & $\begin{array}{l}\text { Aug- } \\
2017\end{array}$ & $\begin{array}{l}\text { Feb- } \\
2018\end{array}$ & $\begin{array}{l}\text { May- } \\
2018\end{array}$ & $\begin{array}{l}\text { Sep- } \\
2018\end{array}$ \\
\hline \multirow{2}{*}{ SM-01 } & $\begin{array}{c}\text { Surface } \\
\text { Water }\end{array}$ & 20.3 & 22.5 & 21.5 & 1.5 & 3.03 & 0.83 & 0.88 & 0.91 & 1.13 & 0.57 & 0.5 & 0.62 & 2.71 & 1.44 & 1.39 & 1.5 \\
\hline & $\begin{array}{l}\text { Bottom } \\
\text { Water }\end{array}$ & 26.4 & 15.85 & 14.9 & 2.01 & 3.95 & 0.95 & 0.75 & 0.99 & 1.36 & 0.7 & 0.66 & 0.73 & 3.36 & 1.9 & 1.85 & 2.01 \\
\hline \multirow{2}{*}{ SM-02 } & $\begin{array}{c}\text { Surface } \\
\text { Water }\end{array}$ & 18.7 & 25 & 19.15 & 0.07 & 2.84 & 0.4 & 2.12 & 0.46 & 0.95 & 0.81 & 0.77 & 0.86 & 2.58 & 0.03 & 0.58 & 0.07 \\
\hline & $\begin{array}{l}\text { Bottom } \\
\text { Water }\end{array}$ & 25.2 & 17.25 & 14.1 & 0.13 & 3.73 & 2.94 & 0.34 & 2.99 & 1.19 & 0.96 & 0.92 & 1 & 3.24 & 0.08 & 0.58 & 0.13 \\
\hline \multirow{2}{*}{ SM-03 } & $\begin{array}{c}\text { Surface } \\
\text { Water }\end{array}$ & 18.1 & 25.3 & 20.3 & 2.05 & 2.78 & 1.77 & 1.73 & 1.65 & 0.9 & 0.85 & 0.82 & 0.75 & 2.52 & 2.2 & 1.8 & 2.05 \\
\hline & $\begin{array}{l}\text { Bottom } \\
\text { Water }\end{array}$ & 24.8 & 19.2 & 14.9 & 2.9 & 3.67 & 2.57 & 2.29 & 2.44 & 1.12 & 1 & 0.93 & 0.9 & 3.17 & 3 & 2.76 & 2.9 \\
\hline
\end{tabular}


Oceanography \& Fisheries Open access Journal

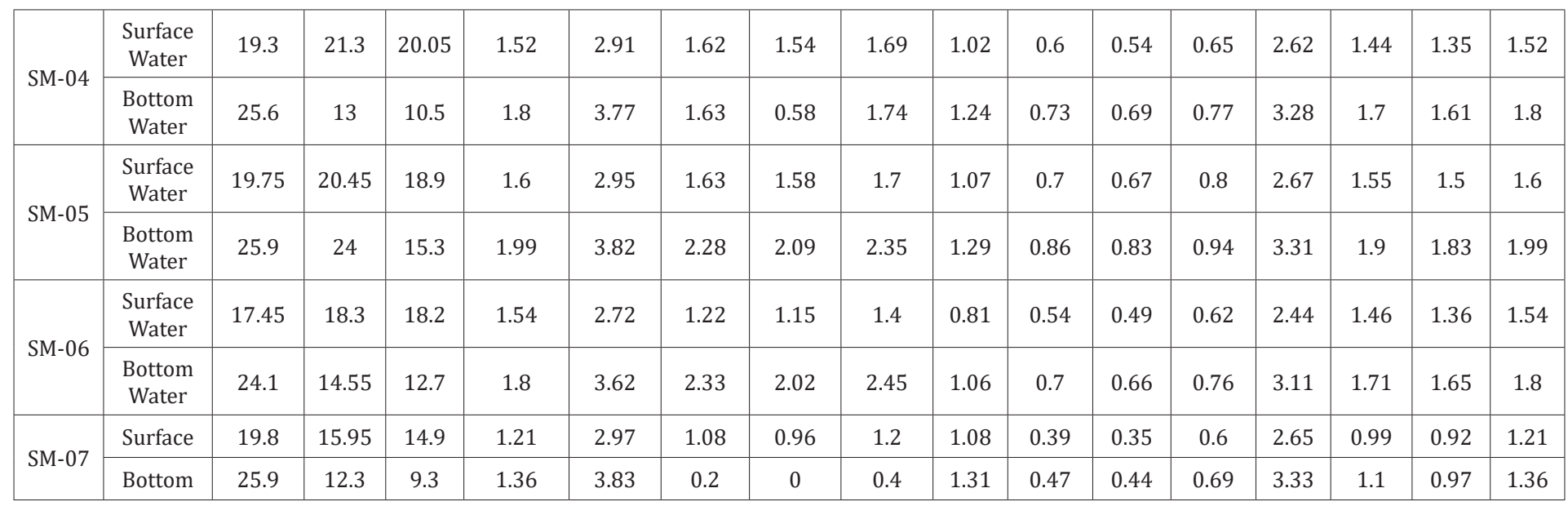

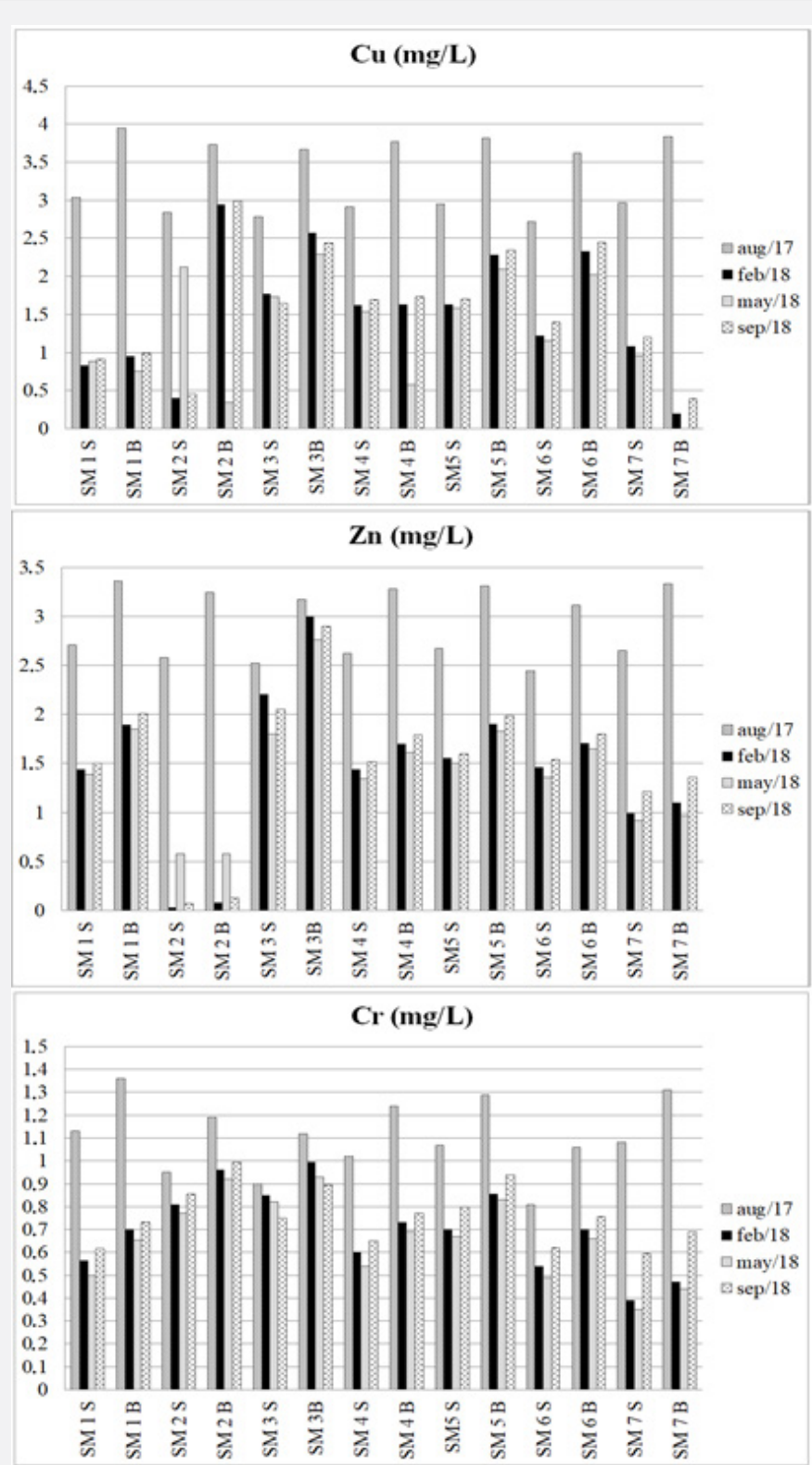

Figure 5: Seasonal variation of Heavy Metals levels in water. 
Table 2: Total Organic Carbon sediment content along Brazilian coast.

\begin{tabular}{|c|c|c|}
\hline Author & Study Site & Total Organic Carbon Content (\%) \\
\hline Present Study & Harbor area São Marco Bay & $0.54-0.91$ \\
\hline Ribeiro et al., 2008 & Guanabara Bay & $0.82-10.60$ \\
\hline Martins et al., 2018 & NE Sector of Guanabara Bay & $0.05-6.1$ \\
\hline Vilela et al., 2003 & Guanabara Bay & $0.06-4.73$ \\
\hline Rodrigues et al., 2017 & Sepetiba Bay & $0.95-2.7$ \\
\hline Costa et al., 2011 & Todos os Santos Bay & $0.12-3.5$ \\
\hline Venturini et al., 2004 & Todos os Santos Bay & $0.8-8.6$ \\
\hline Perina et al., 2018 & São Vicente Estuarine System & $0.10-2.86$ \\
\hline Burone et al., 2003 & Ubatuba Bay & $0.67-4.64$ \\
\hline Alexandre et al., 2006 & Babitonga Bay & \\
\hline
\end{tabular}

Many researchers suggested the direct relationship between levels of pollutants and the availability of fine sediments [5456]. This process is explained adsorption, co-precipitation, and complexing reactions of metals on particle surfaces [57]. In the present study, results exposed the dominance of fine sand (Figure 6), suggesting the influence of macrotidal currents typical in São Marco Bay [42] on preventing mud accumulation. Furthermore, according to Manning et al. [58] tidal currents are very important for sediment distribution in tide-dominated ecosystems. Low levels of organic matter were recorded (between 0.54 and 0.91 $\%)$, confirming that low organic matter concentration results for sediments with coarser grain size particles [59-61]. Additionally, a Spearman test revealed no significant correlation between grain size and organic carbon content.

Heavy metals levels showed relatively low concentrations in sediments (Table 3). The concentrations of $\mathrm{Hg}$ and $\mathrm{Cd}$ in the sediment showed values below the method detection limit. The concentration of $\mathrm{Pb}$, on the other hand, ranged from $0.49 \mathrm{mg}$ $\mathrm{Kg}^{-1}$ in February to $1.63 \mathrm{mg} \mathrm{Kg}^{-1}$ in May. A lower concentration of $\mathrm{Pb}$ was recorded in the sampling stations SM-01 and SM-02. Surface sediments concentration of $\mathrm{Cu}$ ranged from $1.38 \mathrm{mg}$ $\mathrm{Kg}^{-1}$ in February to $1.95 \mathrm{mg} \mathrm{Kg}^{-1}$ in February. For the sediment's $\mathrm{Zn}$ concentration, the values ranged from $2.17 \mathrm{mg} \mathrm{Kg}^{-1}$ in May to3.92 $\mathrm{mg} \mathrm{Kg}^{-1}$ in October. Seasonal data show that during the study period the sediments' Zn content was lower in rainy season $\left(152.76 \pm 46.44 \mathrm{mg} \mathrm{Kg}^{-1}\right)$ compared to the values of dry (198.70 $\left.\pm 86.09 \mathrm{mg} \mathrm{Kg}^{-1}\right)$ and rainy $\left(211.27 \pm 98.46 \mathrm{mg} \mathrm{Kg}^{-1}\right)$ seasons. $\mathrm{Cr}$ and Ni varied between $1.65-3.56 \mathrm{mg} \mathrm{Kg}^{-1}$ and 1.38-1.92 $\mathrm{mg} \mathrm{Kg}^{-1}$ respectively. Finally, as concentrations varied between, 1.12 and $1.84 \mathrm{mg} \mathrm{Kg}^{-1}$.

Table 3: Sediment analysis results.

\begin{tabular}{|c|c|c|c|c|c|c|c|c|}
\hline Parameter & Date & SM-01 & SM-02 & SM-03 & SM-04 & SM-05 & SM-06 & SM-07 \\
\hline \multirow{4}{*}{ Nitrogen (mg Kg-1) } & August/2017 & 47 & 54 & 49.6 & 61.2 & 63.4 & 54.8 & 69.8 \\
\hline & February/2018 & 44 & 63 & 43.5 & 58.3 & 59.7 & 56.5 & 71.2 \\
\hline & May/2018 & 62 & 58 & 54.1 & 63.1 & 64.12 & 48.4 & 74.2 \\
\hline & September/2018 & 74 & 62 & 73.2 & 58.72 & 81.12 & 62.13 & 69.42 \\
\hline \multirow{4}{*}{ Phosphorus (mg Kg ${ }^{-1}$ ) } & August/2017 & 408 & 400 & 412 & 419 & 402 & 424 & 432 \\
\hline & February/2018 & 398 & 401 & 392 & 388 & 389 & 412 & 445 \\
\hline & May/2018 & 411 & 399 & 404 & 414 & 396 & 427 & 418 \\
\hline & September/2018 & 395 & 405 & 419 & 403 & 417 & 414 & 406 \\
\hline \multirow{4}{*}{ TOC (\%) } & August/2017 & 0.67 & 0.62 & 0.7 & 0.73 & 0.65 & 0.76 & 0.79 \\
\hline & February/2018 & 0.59 & 0.58 & 0.64 & 0.6 & 0.61 & 0.78 & 0.81 \\
\hline & May/2018 & 0.72 & 0.64 & 0.72 & 0.54 & 0.72 & 0.84 & 0.67 \\
\hline & September/2018 & 0.84 & 0.76 & 0.83 & 0.65 & 0.83 & 0.91 & 0.79 \\
\hline
\end{tabular}


Oceanography \& Fisheries Open access Journal

\begin{tabular}{|c|c|c|c|c|c|c|c|c|}
\hline \multirow{4}{*}{ Copper (mg Kg $\left.{ }^{-1}\right)$} & August/2017 & 0.57 & 0.64 & 1.563 & 1.611 & 1.604 & 1.592 & 1.624 \\
\hline & February/2018 & 0.49 & 0.68 & 1.549 & 1.596 & 1.598 & 1.588 & 1.598 \\
\hline & May/2018 & 0.63 & 0.49 & 1.623 & 1.614 & 1.631 & 1.496 & 1.477 \\
\hline & September/2018 & 0.59 & 0.52 & 1.458 & 1.712 & 1.582 & 1.532 & 1.511 \\
\hline \multirow{4}{*}{ Chrome (mg Kg-1) } & August/2017 & 2.239 & 2.414 & 3.32 & 3.46 & 3.55 & 3.41 & 3.56 \\
\hline & February/2018 & 2.114 & 2.112 & 3.26 & 3.39 & 3.38 & 3.35 & 3.48 \\
\hline & May/2018 & 1.802 & 2.063 & 3.12 & 3.56 & 3.19 & 3.42 & 3.27 \\
\hline & September/2018 & 1.651 & 1.894 & 2.97 & 2.92 & 3.03 & 3.28 & 3.19 \\
\hline \multirow{4}{*}{ Nickel (mg Kg $\left.{ }^{-1}\right)$} & August/2017 & 1.66 & 1.75 & 1.68 & 1.72 & 1.79 & 1.73 & 1.79 \\
\hline & February/2018 & 1.54 & 1.52 & 1.55 & 1.64 & 1.72 & 1.69 & 1.67 \\
\hline & May/2018 & 1.63 & 1.39 & 1.38 & 1.75 & 1.84 & 1.6 & 1.67 \\
\hline & September/2018 & 1.47 & 1.77 & 1.49 & 1.84 & 1.92 & 1.57 & 1.72 \\
\hline \multirow{4}{*}{ Zinc (mg Kg $\left.{ }^{-1}\right)$} & August/2017 & 2.62 & 2.73 & 3.6 & 3.8 & 3.8 & 3.55 & 3.92 \\
\hline & February/2018 & 2.39 & 2.48 & 3.3 & 3.6 & 3.6 & 3.48 & 3.85 \\
\hline & May/2018 & 2.24 & 2.17 & 2.98 & 3.23 & 3.2 & 3.33 & 3.72 \\
\hline & September/2018 & 2.41 & 2.29 & 3.09 & 3.02 & 3.11 & 3.44 & 3.54 \\
\hline \multirow{4}{*}{ Arsenic $\left(\mathrm{mg} \mathrm{Kg}^{-1}\right)$} & August/2017 & 2.62 & 2.73 & 3.6 & 3.8 & 3.8 & 3.55 & 3.92 \\
\hline & February/2018 & 2.39 & 2.48 & 3.3 & 3.6 & 3.6 & 3.48 & 3.85 \\
\hline & May/2018 & 2.24 & 2.17 & 2.98 & 3.23 & 3.2 & 3.33 & 3.72 \\
\hline & September/2018 & 2.41 & 2.29 & 3.09 & 3.02 & 3.11 & 3.44 & 3.54 \\
\hline
\end{tabular}

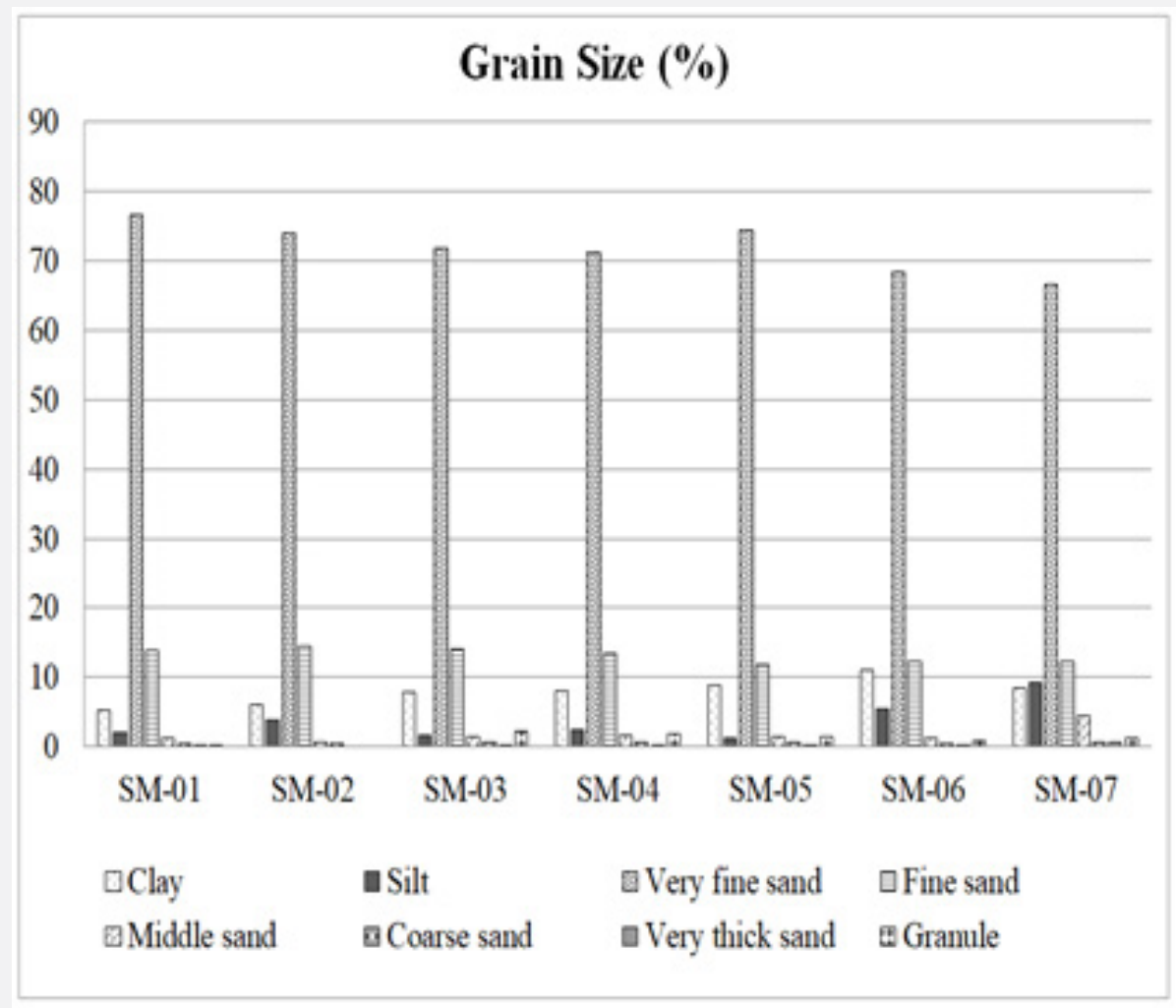

Figure 6: Grain size results. 
In the present study, Canadian sediment quality guidelines (Threshold Effect Level - TEL and Probable Effect Level - PEL) [51] and the average concentrations of heavy metal in UCC are used to compare with heavy metals concentrations in surface sediments [62] (Table 4). Although they were developed for freshwater environments, the limits suggested by MacDonald et al. [51] can be considered conservative, as the precipitates formed in the sea water have extremely low solubilities at surface water pHs (8.1-8.3) [63], as recorded in the present study. Heavy metals concentrations in sediments recorded in the present study suggest no risk to the local biotic community [64-70].

Concerning the statistical treatment (ANOVA), no significant differences were found among surveys. The significant correlation between heavy metals suggested the same onshore origin or similar responses in relation to environmental parameters [7178] (Table 5). The heavy metal concentrations presented relatively low levels in the sediments. All the Igeo results confirmed the sediment from harbor site as "unpolluted to moderated polluted" for all the studied metals since the index remained between 0.59 and 0.76 [78-85] (Table 6).

Table 4: Concentrations of heavy metals in sediment in estuaries in Brazil , global average, TEL and PEL.

\begin{tabular}{|c|c|c|c|c|c|c|c|c|c|c|c|c|c|c|}
\hline Local: & \multicolumn{2}{|c|}{$\begin{array}{c}\mathrm{Pb}\left(\mathrm{mg} \mathrm{Kg}^{-1}\right) \\
\text { Min-Max }\end{array}$} & \multicolumn{2}{|c|}{$\begin{array}{l}\text { As (mg Kg- } \\
\text { 1) Min-Max }\end{array}$} & \multicolumn{2}{|c|}{$\underset{\text { Min-Max }}{\mathrm{Cd}\left(\mathrm{mg} \mathrm{Kg}^{-1}\right)}$} & \multicolumn{2}{|c|}{$\begin{array}{l}\mathrm{Zn}\left(\mathrm{mg} \mathrm{Kg}^{-1}\right) \\
\text { Min-Max }\end{array}$} & \multicolumn{2}{|c|}{$\underset{\text { Min-Max }}{\operatorname{Cr}\left(\mathrm{mg} \mathrm{Kg}^{-1} 1\right)}$} & \multicolumn{2}{|c|}{$\begin{array}{c}\mathrm{Cu}\left(\mathrm{mg} \mathrm{Kg}{ }^{-1}\right) \\
\text { Min-Max }\end{array}$} & \multicolumn{2}{|c|}{$\begin{array}{c}\mathrm{Ni}\left(\mathrm{mg} \mathrm{Kg}{ }^{-1}\right) \\
\text { Min-Max }\end{array}$} \\
\hline $\begin{array}{l}\text { São Marcos Bay } \\
\text { (present study) }\end{array}$ & 0.49 & 1.71 & 1.12 & 1.84 & \multicolumn{2}{|c|}{$<0.15$} & 2.17 & 3.92 & 1.651 & 3.56 & 1.38 & 1.95 & 1.38 & 1.92 \\
\hline Ribeira Bay ${ }^{\mathrm{a}}$ & 0.02 & 0.14 & & - & \multicolumn{2}{|c|}{$<0.002$} & -0.26 & 164 & \multicolumn{2}{|c|}{-} & 0.03 & 0.23 & $<0.05$ & 0.36 \\
\hline $\begin{array}{c}\text { Todos os Santos } \\
\text { Bay }^{\mathrm{b}}\end{array}$ & 0.16 & 107 & & - & 0.003 & 5.56 & 0.44 & 332 & \multicolumn{2}{|c|}{ - } & 0.1 & 429 & \multicolumn{2}{|c|}{-} \\
\hline Sepetiba Bay ${ }^{c}$ & 6.5 & 85.7 & & - & 0.5 & 8.7 & 18.1 & 795 & \multicolumn{2}{|c|}{23.9} & 2.1 & 166 & \multicolumn{2}{|c|}{-} \\
\hline Guanabara Bay $^{\mathrm{d}}$ & 3.6 & 110 & & - & 0.02 & 2.6 & 78 & 707 & \multicolumn{2}{|c|}{3.5} & 2.4 & 300 & \multicolumn{2}{|c|}{-} \\
\hline Gobal averag $^{\mathrm{ee}}$ (Soil) & \multicolumn{2}{|c|}{19} & & 4 & \multicolumn{2}{|c|}{0.03} & & & \multicolumn{2}{|c|}{75.6} & \multicolumn{2}{|c|}{33} & \multicolumn{2}{|c|}{52} \\
\hline $\mathrm{TEL}^{\mathrm{f}}$ & \multicolumn{2}{|c|}{35} & & 9 & \multicolumn{2}{|c|}{0.6} & & & \multicolumn{2}{|c|}{37.3} & \multicolumn{2}{|c|}{0.6} & \multicolumn{2}{|c|}{18} \\
\hline$P E L^{f}$ & \multicolumn{2}{|c|}{91.3} & & 7 & \multicolumn{2}{|c|}{3.5} & & & \multicolumn{2}{|c|}{90} & \multicolumn{2}{|c|}{3.5} & \multicolumn{2}{|c|}{35.9} \\
\hline
\end{tabular}

Chiappettaet et al. 2016a; CRA 2004b; Lacerdaet et al. 1987 and Marinset al. 1998c; Fonseca et al. 2013d; Wedepohl 1995e; MacDonald et al 2000f.

Table 5: Pearson Test Results.

\begin{tabular}{|c|c|c|c|c|c|c|c|c|c|c|c|c|c|}
\hline & Temp & pH & Turbidity & $\begin{array}{l}\text { D i s s o lved } \\
\text { Oxygen }\end{array}$ & $\begin{array}{l}\text { Salini- } \\
\text { ty }\end{array}$ & Condutibility & Eh & $\mathrm{Cu}$ & $\mathrm{Cr}$ & $\mathbf{P}$ & $\mathbf{F e}$ & Mn & Zn \\
\hline Temp & 1 & & & & & & & & & & & & \\
\hline $\mathrm{pH}$ & 0.25 & 1 & & & & & & & & & & & \\
\hline Turbidity & 0.22 & 0.07 & 1 & & & & & & & & & & \\
\hline $\begin{array}{l}\text { Dissolved Oxy- } \\
\text { gen }\end{array}$ & -0.19 & -0.14 & -0.35 & 1 & & & & & & & & & \\
\hline Salinity & -0.18 & -0.62 & -0.28 & 0.21 & 1 & & & & & & & & \\
\hline Condutivity & -0.2 & $-0.56^{*}$ & -0.33 & 0.17 & $0.93^{*}$ & 1 & & & & & & & \\
\hline Eh & -0.35 & -0.1 & -0.04 & 0.28 & -0.19 & -0.22 & 1 & & & & & & \\
\hline $\mathrm{Cu}$ & $-0.58 *$ & -0.16 & -0.25 & 0.22 & 0.15 & 0.24 & 0.36 & 1 & & & & & \\
\hline $\mathrm{Cr}$ & $-0.62^{*}$ & -0.18 & -0.13 & 0.24 & 0.16 & 0.21 & 0.32 & $0.83^{*}$ & 1 & & & & \\
\hline $\mathrm{P}$ & -0.28 & 0.28 & $-0.55^{*}$ & 0.38 & 0.05 & 0.17 & 0.02 & 0.42 & 0.36 & 1 & & & \\
\hline $\mathrm{Fe}$ & -0.45 & -0.08 & -0.27 & 0.07 & -0.01 & 0.05 & 0.36 & $0.70^{*}$ & $0.68^{*}$ & 0.37 & 1 & & \\
\hline $\mathrm{Mn}$ & $-0.64 *$ & -0.12 & -0.23 & 0.3 & 0.16 & 0.19 & 0.44 & $0.84 *$ & $0.90^{*}$ & 0.45 & $0.77^{*}$ & 1 & \\
\hline $\mathrm{Zn}$ & $-0.56^{*}$ & -0.11 & -0.25 & 0.22 & 0.1 & 0.12 & 0.51 & $0.71 *$ & $0.64^{*}$ & 0.39 & $0.77^{*}$ & $0.88^{*}$ & 1 \\
\hline
\end{tabular}

Bold $^{*}=$ significant correlation $(p<0.05)$

Table 6: Annual average of Geo accumulation Index $\left(I_{g e o}\right)$ results.

\begin{tabular}{|c|c|c|c|c|c|c|}
\hline & Zn & $\mathrm{Cu}$ & $\mathrm{Ni}$ & $\mathrm{Cr}$ & $\mathrm{Pb}$ & $\mathrm{As}$ \\
\hline SM 1 & 0.62 & 0.63 & 0.62 & 0.62 & 0.63 & 0.72 \\
\hline SM 2 & 0.62 & 0.64 & 0.62 & 0.62 & 0.63 & 0.74 \\
\hline
\end{tabular}




\begin{tabular}{|l|l|l|l|l|l|l|}
\hline SM 3 & 0.59 & 0.64 & 0.62 & 0.63 & 0.69 & 0.75 \\
\hline SM 4 & 0.64 & 0.64 & 0.62 & 0.64 & 0.7 & 0.76 \\
\hline SM 5 & 0.64 & 0.64 & 0.62 & 0.64 & 0.7 & 0.76 \\
\hline SM 6 & 0.64 & 0.64 & 0.62 & 0.62 & 0.69 & 0.75 \\
\hline SM 7 & 0.63 & 0.64 & 0.61 & 0.64 & 0.69 & 0.76 \\
\hline
\end{tabular}

\section{Conclusion}

The region was characterized by high hydrodynamics, with an important influence of oceanic waters, which promotes oxygenation and high $\mathrm{pH}$, and prevents water column stratification. São Marco estuarine waters presented strong physicochemical variations during the study, suggesting a significant climatological influence on the water chemistry. Despite the low concentrations of heavy metals in the sediment, high levels of metals were observed in the water. This aspect was confirmed by the sandy grain size found in the sediment samples collected and the low organic carbon concentrations, highlighting the importance of the currents that added to the proximity of the sampling stations to the open sea, the minor industrial and urban concentration in the study site as the main factors controlling the quality of the environmental conditions.

\section{Acknowledgment}

This research was funded by SNP (Secretaria Nacional de Portos). The authors are as well thankful for the Geology and Geophysics Department/LAGEMAR at UFF (Universidade Federal Fluminense), and CAPES (Coordenação de Aperfeiçoamento de Pessoal de Nível Superior) for the infrastructure and administrative support.

\section{References}

1. Galkus A, Joksas K, Stakeniene R, Lagunaviciene L (2012) Heavy metal contamination of habor bottom sediments. Polish Journal of Environmental Studies 6: 1583-1594.

2. Tang JYM, Aryal R, Deletic A, Gernjak W, Glenn E, et al. (2013) Toxicity characterization of urban stormwater with bioanalytical tools. Water Research 47(1): 5594-5606.

3. Maslennikova S, Larina N, Larin S (2012) The effect of sediment grain size on heavy metal content. Lakes Reservoirs and Ponds 6(1): 43-54.

4. Kwiatkowska-Malina J (2018) Functions of organic matter in polluted soils: The effect of organic amendments on phytoavailability of heavy metals. Applied Soil Ecology 123: 542-545.

5. Lepland A, Andersen TRJ, Lepland A, Arp HPH, Alve E, et al. (2010) Sedimentation and chronology of heavy metal pollution in Oslo harbor, Norway. Marine Pollution Bulletin 60: 1512-1522.

6. Srebotnjak T, Sherbinin G, Carr A, Rickwood C (2012) A global water quality index and hot-deck imputation of missing data. Ecological Indicators 17: 108-119.

7. Su S, Mi X, Xu X, Zhang Z, Wu J, et al. (2013) Spatial determinants of hazardous chemicals in surface water of Qiantang River, China. Ecological Indicators 24:375-381.

8. Islam M, Han S, Masunaga S (2014) Assessment of trace metal contamination in water and sediment of some rivers in Bangladesh. Journal Water Environment Technology 12: 109-121.
9. Bołzan B D (2014) Effect of heavy metals on living organisms. World Scientific News 5: 26-34.

10. Tchounwou P, Yedjou CG, Patlolla AK, Sutton DJ (2014) Heavy Metals Toxicity and the Environment. Molecular Clinical and Environmental Toxicology 101: 133-164.

11. Jaishankar M, Tseten T, Anbalagan N, Mathew BB, Beeregow da KN (2014) Toxicity, mechanism and health effects of some heavy Metals. Interdiscip Toxicol 7(2): 60-72.

12. Khan MI, Khisroon M, Khan A, Gulfam N, Siraj M, et al. (2108) Bioaccumulation of Heavy Metals in Water, Sediments, and Tissues and Their Histopathological Effects on Anodontacygnea (Linea, 1876) in Kabul River, Khyber Pakhtunkhwa, Pakistan. BioMed Research International.

13. Violante A, Cozzolino V, Perelomov L, Caporale AG, Pigna M (2010) Mobility and Bioavailability Of Heavy Metals And Metalloids in Soil Environments. Journal of Soil Science and Plant Nutrition 10(3): 268-292.

14. Zapata F C C, Villanueva M C, Esquivel R A P, Payano I G U (2017) Bioaccumulation of heavy metals in Oncorhynchus mykiss for export at production centers in the Peruvian Central Highlands. Rev Ambient Água 12(4): 527-542.

15. Yang ZP, Lu WX, Long YQ Bao XH and Yang Q C (2011) Assessment of heavy metals contamination in urban topsoil from Changchun City, China. Journal of Geochemical Exploration 108(1): 27-38.

16. Maata M, Singh S (2008) Heavy metal pollution in Suva harbor sediments, Fiji. Environmental Chemistry Letters 6: 113-118.

17. Ciszewski DSZ, Matys T G (2016) A Review of Flood-Related Storage and Remobilization of Heavy Metal Pollutants in River Systems. Water Air and Soil Pollution 227: 239.

18. Davutluoglu OI, Seckin G, Ersu CB, Yilmaz T, SARI B (2011) Heavy metal content and distribution in surface sediments of the Seyhan River, Turkey. Joutnal of Environment Management 92(9): 2250-2259.

19. Popenda A (2014) Effect of redox potential on heavy metals and As behavior in dredged sediments. Desalination and Water Treatment 52: 1921.

20. Pfeiffer WC, Fiszman M, Lacerda LC (1988) Pesquisas de metais pesados em ambientes costeiros brasileiros. In: Seeliger U, de Lacerda LD, Patchineelam SR (eds.). Metais em ambientes costeiros da América Latina. Springer, Berlim, Heidelberg.

21. Buruaem L M, Hortellani M A, Sarkis J E, Costa-Lotufo LAV, Abessa DMS (2012) Contamination of port zone sediments by metals from Large Marine Ecosystems of Brazil. Marine Pollution Bulletin 64(3): 479-488.

22. Souza Filho PWM, Paradella WR (2001) Estudo da Geomorfologia de Ambientes Costeiros Tropicais Umidos a partir das imagens de sensores remotos. Revista Pesquisas 28(2): 359-368.

23. Barthem R B (1995) Development of commercial fisheries in the Amazon basin and consequences for fish stocks and subsistence fishing. In: $\mathrm{M}$ Clüsener-Goot, I SACHS (Eds.). Brazilian perspectives on sustainable development of the Amazon Region: 175-204. UNESCO, Paris.

24. Honorato da Silva M, Silva-Cunha M G G, Passavante JZ O, Grego CKS, Muniz K (2009) Estrutura sazonal e espacial do microfitoplâncton no estuário tropical do rio Formoso, PE, Brasil. Acta Botânica Brasílica 23: 335-368. 
25. González-Gorbeña E, Rosman PCC, Qassim RY (2015) Assessment of the tidal current energy resource in São Marcos Bay, Brazil. Journal of Ocean Engineering and Marine Energy 1: 421-433.

26. Souza-Filho PWM, Sales MEC, Prost MTRC, Costa FR, Souza FMO (2005) Zona Costeira Amazônica: $O$ cenário regional e os indicadores bibliométricos em C\&T. In: Souza Filho P W M, Cunha E R S P, Sales M E C, Souza L F M O \& Costa F R (org.) Bibliografia da Zona Costeira Amazônica. Belém: Museu Paraense Emilio Goeldi/Universidade Federal do Pará/ Petrobras.

27. Amaral R F and Alfredini P (2010) Modelação hidrossedimentológica no canal de acesso do complexo portuário do Maranhão. RBRH - Revista Brasileira de Recursos Hídricos 15: 5-14.

28. Carvalho-Neta R N F, Torres-Junior A R and Abreu-Silva A L (2012) Biomarkers in Catfish Sciadesherzbergii (Teleostei: Ariidae) from Polluted and non-polluted areas (São Marcos' Bay, Northeastern Brazil). Applied Biochemistry and Biotechnology 166(5): 1314-1327.

29. Aspila K I, Agemian H, Chau ASY (1976) A semi-automated method for the determination of inorganic, organic and total phosphate in sediments. Analyst 101(1200): 187-197

30. USEPA (1992) Test Methods for Evaluating Solid Waste, Physical/Chemical Methods. ( $3^{\text {rd }}$ edn.) USEPA, SW-846, Environmental Protection Agency, United States.

31. Knezovich J P (1994) Chemical and biological factors affecting bioavailability of contaminants in seawater. In: J L Hamelink, P F Landrum, H L Bergman, W H Benson (eds.). Bioavailability: Physical, Chemical, and Biological Interactions. Lewis Publishers, Boca Raton, Florida, US, Pp. 23 38.

32. Muller G (1969) Index of Geo-Accumulation in Sediments of the Rhine River. Geo Journal 2: 108-118.

33. Rudnick RL, Gao S (2003) The Composition of the Continental Crust. In Holland HD, Turekian KK (Eds.), Treatise on Geochemistry, The Crust, Elsevier-Pergamon, Oxford, England, Pp. 1-64.

34. Fonseca EM, Baptista Neto JA, Pereira MPS, Silva CG, Arantes Junior J D (2014) Study of pollutant distribution in the Guaxindiba Estuarine System - SE Brazil. Marine Pollution Bulletin 82: 45-54.

35. Hopkinson C and Smith M E (2004) Estuarine respiration: An overview of benthic, pelagic, and whole system respiration. Respiration in Aquatic Ecosystems.

36. Higashizono K, Yamaguchi H, Tada K, Ichimi K (2016) Seasonal variation of primary productivity in the Shinkawa River estuary, eastern Seto Inland Sea. Japan La Mer 54: 55-72.

37. Iriarte A, Aravena G, Villate F, Uriarte I, Ibáñez B, et al. (2010) Dissolved oxygen in contrasting estuaries of the Bay of Biscay: effects of temperature, river discharge and chlorophyll a. Marine Ecology Progress Series 418: 57 71.

38. Rodrigues CAL, Ribeiro RP, Santos NB, Almeida ZS (2016) Patterns of mollusc distribution in mangroves from the São Marcos Bay, coast of Maranhão State, Brazil. Acta Amazonica 46(4): 391-400.

39. Zeebe RE, Wolf-Gladrow D (2001) CO2 in Seawater: Equilibrium, Kinetics, Isotopes. ( $1^{\text {st }}$ edn). Amsterdam: Elsevier, Pp. 346.

40. Paerl HW, Pinckney JL, Fear JM, Peierls BL (1998) Ecosystem responses to internal watershed organic matter loading: consequences for hypoxia in the eutrophying Neuse River Estuary, North Carolina, USA. Marine Ecology Progress Series 166: 17-25.

41. Kemp W M, Testa JM, Conley DJ, Gilbert D, Hagy J D (2009) Temporal responses of coastal hypoxia to nutrient loading and physical controls. Biogeosciences 6 (12): 2985- 3008.

42. Cavalcanti L F, Azevedo-Cutrim A C G, Oliveira A L L, Furtado J A, Araújo $\mathrm{B}$ de $\mathrm{O}$, et al. (2018) Structure of microphytoplankton community and environmental variables in a macrotidal estuarine complex, São Marcos Bay, Maranhão - Brazil. Brazilian Journal of Oceanography 66(3): 283-300.

43. Cloern JE, Foster SQ Kleckner A E (2014) Phytoplankton primary production in the world's estuarine-coastal ecosystems. Biogeosciences 11: $2477-2501$.

44. Telesh I V, Khlebovich VV (2010) Principal processes within the estuarine salinity gradient: A review. Marine Pollution Bulletin 61(4-6): 149-155.

45. Karbassi A R, Heidari M, Vaezi A R, Valikhani Samani A R, Fakhraee M, et al. (2013) Effect of $\mathrm{pH}$ and salinity on flocculation process of heavy metals during mixing of Aras River water with Caspian Sea water. Environmental Earth Sciences 72: 457-465.

46. Middelburg J, Soetaert K (2004) The Role of Sediments in Shelf Ecosystem Dynamics. In: Robinson AR, McCarthy J, Rothschild BJ (Eds.), The Sea, 13

47. Glud R N (2008) Oxygen dynamics of marine sediments. Marine Biology Research 4: 243-289.

48. Middelburg J J and Levin L A (2009) Coastal hypoxia and sediment biogeochemistry. Biogeosciences 6: 1273-1293.

49. Meysman F J R, Middelburg JJ, Heip CHR (2006) Bioturbation: a fresh look at Darwin's last idea, Trends in Ecology \& Evolution 21(12): 688-695.

50. Vicente MAF, Melo GV de, Baptista Neto JA, Oliveira AS de (2016) Phosphorus fractionation distribution in Guapimirim estuary: SE Brazil. SpringerPlus 5:1406

51. Carvalho G P de, Cavalcante P R S, Castro A C L de and Rojas M O A I (2000) Preliminary Assessment of Heavy Metal Levels in Mytella Falcata (Bivalvia, Mytilidae) From Bacanga River Estuary, São Luís, State Of Maranhão, Northeastern Brazil. Revista Brasileira de Biologia 60(1): 11-16.

52. Burone L, Muniz P, Pires-Vanin AMS and Rodrigues M (2003) Spatial distribution of organic matter in the surface sediments of Ubatuba Bay (Southeastern - Brazil). Anais da Academia Brasileira de Ciências 75(1): 77-90.

53. Alexandre MR, Huang Y, Madureira L A S (2006) Avaliação De Compostos Orgânicos Em Sedimentos Superficiais Da Baía De Babitonga, Santa Catarina, Brasil. Geochimica Brasiliensis 20(2): 208-218.

54. Seshan BRR, Natesan U, Deepthi K (2010) Geochemical and statistica approach for evaluation of heavy metal pollution in core sediments in southeast coast of India. International Journal of Environmental Science and Technology 7(2): 291-306.

55. Bouchez J, Gaillardet J, France Lanord C, Maurice L and Dutra-Maia P (2011) Grain size control of river suspended sediment geochemistry: Clues from Amazon River depth profiles. Geochemistry Geophysics Geosystems 12(3): $1-24$

56. Zhao H, Wang X, Li X (2017) Quantifying Grain-Size Variability of Metal Pollutants in Road-Deposited Sediments Using the Coefficient of Variation. Int J Environ Res Public Health 14(8): 850.

57. Parizanganeh A (2008) Grain Size Effect in Trace Metals in Contaminated Sediments along the Iranian Coast of the Caspian Sea. Proc Taal: The 12th World Lake Conference 329-236.

58. Manning AJ, Langston WJ, Jonas PJC (2010) A review of sediment dynamics in the Severn Estuary: Influence of flocculation. Marine Pollution Bulletin 61(1-3): 37-51.

59. Soto-Jimenez M, Paez-Osuna F, Ruiz-Fernandez AC (2003) Geochemical evidence of the anthropogenic alteration of trace metal composition of the sediments of Chiricahueto Marsh (SE Gulf of California). Environmental Pollution 125(3): 423-432.

60. Coppola L, Gustafsson O, Andersson P, Eglinton T I, Uchida M, et al. (2007) The importance of ultrafine particles as a control on the distribution of organic carbon in Washington Margin and Cascadia Basin sediments. Chemical Geology 243: 142-156. 
61. Marchand C, Lallier-Vergès E, Disnar J R, Kéravis D (2008) Organic carbon sources and transformations in mangrove sediments: A rockeval pyrolysis approach. Organic Geochemistry 39: 408-421.

62. Wedepohl KH (1995) The composition of the continental crust. Geochimica et Cosmochimica Acta 59(7): 1217-1232.

63. Ansari T M, Marr IL, Tari QN (2004) Metais Pesados na Perspectiva da Poluição Marinha - Uma Mini Revisão. Revista de Ciências Aplicadas 4 (1): 1-20.

64. Celino J J, de Oliveira O M C, Hadlich G M, Queiroz A F de S, Garciak S (2008) Assessment of contamination by trace metals and petroleum hydrocarbons in sediments from the tropical estuary of Todosos Santos Bay, Brazil. Revista Brasileira de Geociências 38(4): 753-760.

65. Chiappetta J, Machado W, Santos J, Lessa J (2016) Trace metal bioavailability in sediments from a reference site, Ribeira Bay, Brazil. Marine Pollution Bulletin 106(1-2): 395-399.

66. Costa AB, Novotny EH, Bloise AC, Azevedo ER, Bonagamba TJ, et al. (2011) Characterization of organic matter in sediment cores of the Todos os Santos Bay, Bahia, Brazil, by elemental analysis and 13C NMR. Marine Pollution Bulletin 62(8): 1883-1890.

67. CRA (2004) Diagnóstico da concentração de metais pesados e hidrocarbonetos de petróleo nos sedimentos e biota da Baía de Todos os Santos. Consórcio BTS Hydros CH2MHILL. Governo do Estado da Bahia, Salvador.

68. Fonseca EM, Baptista Neto JA, Silva CG, Mc Alister JJ, Smith BJ, et al. (2013) Stormwater impact in Guanabara Bay (Rio de Janeiro): Evidences of seasonal variability in the dynamic of the sediment heavy metals. Estuarine Coastal and Shelf Science 130: 161-168.

69. Gäbler HE (1997) Mobility of heavy metals as a function of $\mathrm{pH}$ of samples from an overbank sediment profile contaminated by mining activities. Journal of Geochemical Exploration 58: 185-194.

70. Gonzalez-Macias C, Schifter I, Lluch-Cota DB, Mendez-Rodriguez L, Hernandez-Vazquez S (2006) Distribution, Enrichment and Accumulation of Heavy Metals in Coastal Sediments of Salina Cruz Bay, Mexico. Environmental Monitoring and Assessment 118: 211-230.

71. Karen B, Baird D (2001) Survey of heavy metals in the sediments of the swartkops river estuary, port Elizabeth South Africa. Water SA 27(4): 461466.

72. Koukina SE, Lobus NV, Peresypkin VI, Dara OM, Smurov AV (2016) Abundance, distribution and bioavailability of major and trace elements in surface sediments from the Cai river estuary and Nha Trang Bay (south China sea, Vietnam). Estuarine Coastal and Shelf Science 198: 450-460.

73. Lacerda L D, Rezende C E, Silva C A R, Wasserman J C (1987) Metallic composition of sediments from mangroves of the S. E. Brazilian coast. In: C E Lindberg, T C Hutchinson (eds.). Heavy Metals in the Environment. Proc. 6th Int. Conf., New Orleans, Edinburgh, UK, Pp. 464-466.

74. Maher W, Butler E (1988) Arsenic in the marine environment. Applied Organometallic Chemistry 2: 191-214.

75. Marins RV, Lacerda LD, Paraquetti HHM, Paiva EC, Villas-Boas RC (1998) Geochemistry of mercury in sediments of a sub-tropical coastal lagoon, Sepetiba Bay, Southeastern Brazil. Bulletin of Environmental Contamination and Toxicology 61: 57-64.

76. Martins MVA, Rodrigues R, Pereira E, Miranda P, Laut L, et al. (2018) Organic Pollution in the NE Sector of Guanabara Bay (SE, Brazil). Journal of Sedimentary Environments 3(3): 138-154.

77. Morais J O (1977) Processos de sedimentação na baía de São Marcos, estado do Maranhão, Brasil. Arquivos de Ciências do Mar 17: 153-164.

78. Ni X B, Huang D J, Zeng D Y, Zhang T, Li H L, et al. (2016) The impact of wind mixing on the variation of bottom dissolved oxygen off the Changjiang estuary during summer. Journal of Marine Systems 154: 122-130.

79. Ribeiro LGL, Carreira RS, Wagener ALR (2008) Conteúdo e distribuição de carbono negro em sedimentos do litoral brasileiro (Baía de Guanabara. Journal of the Brazilian Chemical Society 19(7): 1277-1283.

80. Rodrigues SK, Abessa DMS, Rodrigues APC, Soares-Gomes A, Freitas CB, et al. (2017) Sediment quality in a metal-contaminated tropical bay assessed with a multiple lines of evidence approach. Environmental Pollution 228: 265-276.

81. Turekian KK, Wedepohl KH (1961) Distribution of the Elements in Some Major units of the Earth's Crust. Bulletin of the Geological Society of America 72: 175-190.

82. Venturini N, Tommasi LR, Bícego MC, Martins CC (2004) Characterization of the Benthic Environment of a Coastal area Adjacent to an Oil Refinery, Todos Os Santos Bay (Ne-Brazil). Brazilian Journal of Oceanography 52(2): 123-134.

83. Verity PG, Alber M, Bricker SB (2006) Development of hypoxia in wellmixed subtropical estuaries in the southeastern USA. Estuaries and Coasts 29: 665-673.

84. Vilela CG, Sanjinés AES, Ghiselli Jr RO, Mendonça Filho JG, Baptista Neto JA et al. (2003) Search for Bioindicators of Pollution in the Guanabara Bay: Integrations of Ecologic Patterns. Anuário do Instituto de Geociências UFRJ 26: 25-35.

85. Wu Q, Zhou H, Tam N, Tian Y, Tan Y, et al. (2016) Contamination, toxicity and speciation of heavy metals in an industrialized urban river: implications for the dispersal of heavy metals. Marine Pollution Bulletin 104: 153-161.

\section{Your next submission with Juniper Publishers} will reach you the below assets

- Quality Editorial service

- Swift Peer Review

- Reprints availability

- E-prints Service

- Manuscript Podcast for convenient understanding

- Global attainment for your research

- Manuscript accessibility in different formats

( Pdf, E-pub, Full Text, Audio)

- Unceasing customer service

Track the below URL for one-step submission

https://juniperpublishers.com/online-submission.php 